\title{
International Foundations, Agenda Setting and the Non-Profit Sector in South Africa
}

Bhekinkosi Moyo*

\section{Introduction}

That there is a vibrant civil society in South Africa encompassing political, labour, religious, cultural, welfare and developmental organisations, many of which developed as resistance structures to apartheid is not debatable. However what is debatable is the extent to which part of this vibrancy is a result of the society's own commitment or that of its donors ${ }^{1}$ in response to the country's development challenges. The question that we are concerned with is the extent to which the development agenda is owned by development organisations in South Africa and the extent to which it is promoted by international foundations. This is an attempt to interrogate the assumptive argument that the development agenda has not emerged from the country itself but from interaction with foreign agencies (Budlender 1999:357). We locate the whole discussion in the relationship that develops between international donors and local recipient non-governmental organisations. We also make the observation that the extent and manner to which international aid impacts on the development agenda is uneven. We then draw the conclusion that the evidence seems to suggest that the development agenda is promoted by a variety of role players, chief of whom are the third sector, donors and government. However, we also note that the relationship that develops between donors and recipients is complex. There is evidence which suggests that many local $\mathrm{NGOs}^{2}$ are dependent on donor funding. ${ }^{3}$ This opens up a whole set of questions around long-term impact and the feasibility of donor assistance. Partly, this is so because the survival of these

\footnotetext{
* Doctoral candidate (Politics), University of the Witwatersrand, Johannesburg, South Africa. E-mail: bhekinkosimoyo@hotmail.com.
} 
organisations depends not so much on their ability to engage their constituencies, but more upon their ability to persuade the donors. In the long run this could contribute to unhealthy donor-recipient relations. ${ }^{4}$ This could confirm the view that the importance of donor funding in the short term is offset by the dependence that it creates in the long term.

This paper is a result of widely held interviews with international donor foundations and their grantees. ${ }^{5}$ The role that these international agencies have played in supporting the non-profit sector in South Africa cannot be ignored. A huge impact, which manifests itself in a number of ways, has been made in areas such as gender and women's development; strengthening the non-profit sector; institution building; democracy building and good governance; promotion of citizen rights and responsibilities; lobbying for a more enabling environment for the sector; capacity building; economic justice; human rights and democratisation; and community development among others. However this achievement does not preclude the fact that these foundations can call the shots. They certainly have the leverage to do so through their broad priorities. There is evidence which suggests that donors such as these foundations indirectly promote their own agenda and NGOs often model their programmes to suit donor guidelines. At the same time, local NGOs have more power in the relationship than they realise and should exploit it to get donors to support the kinds of programmes that they believe are most important and relevant to their constituencies. Our final point is that the development agenda appears to be the result of a multiple response to South Africa's contextual needs. ${ }^{6}$

\section{Structure of the paper}

We start by framing the conceptual paradigms that we use in the paper. In the first section, we look briefly at the aid and development literature in Africa. We then move to give a snapshot of the state of civil society in South Africa. Lastly we discuss the question, who is promoting the non-profit sector's development agenda in South Africa? 


\section{Framing the Paradigms}

\section{Aid and Development in Africa: Conceptual Paradigms}

There is a considerable amount of literature on aid and (under) development in Africa that has shaped popular discourse. This discourse has tended to assume both theoretical and practical approaches. Carol Lancaster (1999) is perhaps the leading scholar who has identified the two main analytical approaches to investigate the impact aid has had on development. These approaches are contextual and instrumental.

(a) The contextual theory is more theoretical and considers the impact of aid on development primarily as a function of the broader political and economic context in which it is provided (Lancaster 1999: 5). A number of theories are relevant here:

- Dependency theory, which focusses on the relations of power between rich and poor countries or between donors and recipients. According to this theory, strong capitalist countries in the developed world that exploit developing countries are the cause of the lack of development in the Third World. Aid is used as a capitalist tool that reinforces and continues exploitative behaviour, deepening underdevelopment and poverty. ${ }^{7}$ By the same token this could suggest that aid creates much of the misery which it seeks to relieve. And whether or not it relieves all the misery that it creates is yet another area of concern that needs to be further researched. What is important for us is the examination of the validity of this theory with regard to the NPO sector in South Africa. We depart from the point that this theory has not had adequate empirical evidence to support its claims. We hope to test it with some evidence in the context of civil society assistance.

- Deconstructionist theory: which is inspired partly by the great disparity of power between the rich, developed world and the poorer developing regions of Africa, Asia and Latin America. As an anthropological approach, it sought to highlight that the idea of development is an invention of Western capitalism, aimed at creating an extremely efficient apparatus for producing knowledge about, and the exercise of power over, the Third World (Escobar, 
A 1995:9), but with little basis in the realities of that world. Aid is therefore a tool by the donor to exercise power but with little relevance to (and possibly with negative consequences for) the lives of the recipients (Lancaster 1999:6). We acknowledge that this approach also lacks empirical evidence to support its claims. However, taken in its moderate form, it has been productive in its analysis. A famous example is the study by James Ferguson (1990), which examined the impact of aid in Lesotho's rural development project. This approach observed that the project failed to achieve its goals because it used a developmental tool that did not understand the social and political environment in which it was working. For example, poverty was treated as a technical problem rather than a political one. Our chief concern is the extent to which development actors have understood the culture in which they are working and the extent to which they have not. This ties in very well with what we said earlier, that there are arguments that suggest that the development agenda is not locally developed.

- State-Market Failure theory: which in the early 1950s and 60s viewed underdevelopment as a result of the lack of savings and investment in poor countries. Aid was introduced to stimulate growth and reduce poverty ${ }^{8}$ Aid also acts as an incentive to encourage policy and regulatory reforms, which would free markets and stimulate investment and growth. Aid agencies therefore become central in influencing policy in economic and political landscapes. These have emphasised the importance of democratic institutions such as improved governance, transparency, rule of law, elections and so on in improving the environment for investment and development. Seen from this perspective, aid is not necessarily a bad tool. We use this approach to determine the extent to which donor organisations have contributed to the democratisation of South Africa and the extent to which they continue to contribute towards the consolidation of democracy.

(b) The deconstructionist approach is more empirically oriented and evaluates the impact of aid in terms of the success or failure of the projects and programs it finances (Lancaster 1999:5). Within this analysis, literature falls under two categories, one polemical 
and the other more sober. The polemical literature exposes the sins of the aid industry. A typical example of such literature is Graham Hancock's Lords of Poverty: The Power, Prestige, and Corruption of the International Aid Business (1989), which asserts that aid should be terminated because as a tool of development it is fundamentally flawed by misguided policies, bureaucratic inefficiency, self-interest, and corruption of official aid agencies. ${ }^{9}$ The sober literature tends to be based on evaluations, studies and other empirical material. The World Bank's many studies on the statistical relationship between aid flows and economic growth constitute one such category. The general finding has been that when monetary, fiscal and trade policies in recipient countries are taken into account, aid has a positive impact on growth in supporting policy environments (Burnside and Dollar 1996). ${ }^{10}$ The other category is that which states that aid is effective in achieving its goals most of the time.

We build on these approaches to understand the effectiveness of aid on civil society organisations. But we first, let us turn to a discussion of civil society in South Africa.

\section{Civil society in South Africa \\ Explaining the sector}

We are not going to delve into the discussions that have surrounded the concept of civil society in this paper. Instead we give a working definition of civil society and give a brief discussion of its state, size, nature and scope in South Africa. We follow the general trend of using some terms interchangeably. Thus, the terms, third sector, non-governmental sector, voluntary sector, non-profit sector, nonprofit organisations and community based organisations are used interchangeably as if they meant the same thing to refer to the constituents of civil society. The term civil society, in political philosophy, has been contested. Discussions around it have stretched from Hegel, through Marx, Gramsci and Habermas on the one hand and through Durkheim, Simmel and Parsons on the other to its rebirth in the 1990s. These debates have given birth to a wide range of alternative definitions of civil society. In short these range 
from broad based popular participation (Locke, Hobbes) to elite bargaining of one kind or another (Montesquieu) to elite-citizengovernment interchanges (de Tocqueville).

The term today still has as many definitions as there are people defining it. Its ugly face however is that donors are not unanimously agreed on its definition. More often they regard it as the organised arena in society located between the state and the private citizen. For the Mott Foundation, for example, civil society consists of three sectors: namely, public or government, private or for profit business, and voluntary, charitable or nonprofit (Stacey and Aksartova, 2001: 380). And for the Ford Foundation, civil society is broadly constituted but also specific, hence it is not the society as whole. For Ford, civil society's role is to instill a democratic temperament and to monitor and restrain government (Stacey and Aksartova, 2001: 378). As a result of this debate about the meaning of civil society, Bebbington and Riddell note that:

Civil society is a notoriously slippery concept. It has entered donor terminology without careful attention...In many respects the term is used as a code for a set of ideas related to participation, good government, human rights, privatization and public sector reform (Riddell and Bebbington 1995:23).

This debate on civil society is also found in South Africa. The term is contested. A recent research project forming part of the broader 'CIVICUS/South African Non Governmental Organizations Coalition (SANGOCO)' process in developing a common vision of a healthy civil society by the Co-operative for Research and Education (CORE) and the Institute for Democracy in South Africa (IDASA) defined civil society as:

The sphere of organizations and/or associations of organizations located between the family, the state, the government of the day, and the prevailing economic system, in which people with common interests associate voluntarily. Amongst these organizations, they may have common, competing, or conflicting values and interests. (Core/Idasa, 2001: 4) ${ }^{11}$

We use this as our working definition. However we go a step further to distinguish what a non-profit organisation or a non-governmental organisation is. 


\section{Defining a non-profit organisation}

According to a new study on the size and scope of the non-profit sector in South Africa which was modelled according tot the Johns Hopkins Nonprofit Comparative Project, a non-profit organisation must be organised, private, self-governing, non-profit distributing and voluntary. This agrees with the characteristics of civil society organisations in South Africa that are identified by the CIVICUSSANGOCO study. These range from NGOs, CBOs, associationsnetworks of NGOs-CBOs, trade unions and federations, professional associations, employer-business associations and their federations, sports-arts-cultural organisations, religious organisations and independent research institutes.

\section{The size of the non-profit sector in South Africa}

Evidence from the two studies referred to suggests that the nonprofit sector in South Africa is heterogeneous. It ranges from the less sophisticated burial societies to the most professional research institutes. This makes it very difficult to accurately and reliably define its size in numbers. However, the study The Size and Scope of the Non-profit sector in South Africa, estimates that there are 98920 NPOs across all sectors. According to the study, the sectors with the largest number of NPOs are culture and recreation (20 587), social services (22 755), and development and housing (20 382). Other findings about the size of the sector are that the majority of NPOs are less formalised community based organisations concentrated in the poorer communities. No less than 53 percent of all NPOs can be classified as less formalised community-based organisations (i.e. not formally structured as Section 21 companies, trusts, churches, trade unions or co-operatives). Women and black people play a leading role in the NPO sector. According to this study 59 percent of the managerial level of all NPOs surveyed is made up by women. And 60 percent of all full-time employees are women. The study also suggests that the sector is a major economic force. It employs just over half a million people and generating income in excess of R10 billion per year. According to the study, there are 645316 full time equivalent staff employed by the sector, which is equivalent to 9 percent of the formal non-agricultural workforce of 7.6 percent of the 
total non-agricultural workforce. This shows not only the vibrancy of the sector but its contribution to economic development as well. It is here that the part played by donors is also to be appreciated.

\section{Funding to the sector}

Soon after the negotiated transition to democracy in South Africa, there were fears that the sector was experiencing financial problems. The general assumption was that donors had decided to reroute funding to the democratic government especially after 1994.However new findings, for example, those from the International Organization Development (IOD), reveal that international development aid to South Africa has not declined. It averages between R2.3bn and R3bn, with a quarter going to the non-profit sector (Development Update, 2001, Vol.3. No.4: 135). Another study is that of the U.S. Foundations in South Africa, which argue that even though most official donors to civil society in South Africa rerouted their support to the democratic government, U.S. Foundations did not follow this trend. According to this study, U.S. Foundations showed no tendency to scale back their grantmaking to South Africa during the transition to, or consolidation of, democracy (Stacey and Aksartova, 2001: 390). In fact funding from these agencies increased steadily as from 1988 till today. The findings of these studies concur with the findings of The Size and Scope of the Non profit Sector in South Africa (2002), which shows that the non-profit sector had an estimated income of R14bn in 1998, with contributions from government (42 percent, $\mathrm{R} 5.8 \mathrm{bn}$ ), the South African private sector (21 percent, R3bn, private philanthropy and international non-governmental organisations (25 percent, R3.5bn), and service fees and other self generated income (34 percent, R4.6bn).

This section shows that the third sector in South Africa is very huge. It is a force to reckon with. What we want to point out is that this sector has existed for a long time with the support of international donor agencies. The foundations that we investigated in this paper have been active in South Africa as early as the 1980s well before they even set up offices. For all these years in South Africa, the question that we want to ask, how have they been interacting with their grantees? To what extent have they promoted their own 
interests? And to what extent have they been influenced by their grantees in shaping their guidelines? These are complex questions that we do not claim we will be able to answer in full.

\section{Who Calls the Shots?}

\section{'He who pays the Piper, Calls the Tune?'12}

Generally, there is no direct answer to the question of the impact of the aid on agenda setting. First, the impact is uneven and relations are complex. According to Christa. L. Kuljian, director of Mott Foundation in South Africa,

There are cases where support by the donor for an organization can be broad, covering the general operations, general activities and the overall budget. Here there is some flexibility for the organization. In other cases support could be in the form of project funding, thus making it more targeted and thus less flexible on the part of the organization. There are also cases where the donor provides support for the organization's capacity building thus covering strategic planning, organizational development and staff development. This is usually a response to the realization that one cannot have an effective project if one does not have an effective organization. ${ }^{13}$

Secondly, this question pulls together priorities and programme areas. How grantees negotiate the agenda without either alienating their constituencies or losing their donors? There is overwhelming evidence which suggests NGOs are increasingly challenged by donor dependence ${ }^{14}$ and shifts in donor policies. ${ }^{15}$ However, looking at the programmes and projects that agencies such as Mott, Open Society, the Humanistic Institute for International Development (Hivos), Atlantic Philanthropies and Ford have supported in South Africa, it appears that international funding has had a significant impact on local NGOs. Yet the question that cuts across this discussion is whether these NGOs are carrying out their own agendas or the agenda of donors. How do donors decide on their priorities? Are donors influenced by their domestic concerns or they are reacting to what seem to be overriding problems in the recipient country? Does paying the piper necessarily translate into calling the tune? In other words do donors set the development agenda for NGOs because they support them? 
There are mixed opinions regarding the above questions. At this stage we can only say that answers depend on the type of the NGO that is receiving support and the agency supporting it. Intermediary NGOs, like the International Fundraising Consortium, for example, would answer the questions differently from research oriented NGOs like the Centre for the Study of Violence and Reconciliation (CSVR), the Co-Operative for Research and Education (CORE), the Centre for Policy Studies (CPS) etc. Likewise organisations with a diverse funding base would also respond differently.

Organisations with a diverse funding base in most cases find it easy to create healthy donor relations. However, according to Alicia Pieterse, director of INTERFUND, diversifying funding may cause more problems than it seeks to solve. Her words capture the argument clearly:

The most important thing that you must understand about us is where we are placed. We are very much in the middle, we have all these donors in the top and we are funding about 130 organizations some of which are NGOs and others CBOs. In all honesty you cannot begin to know how much time it takes to negotiate upwards. We are all saying we are talking about partnerships and partnerships imply equality, but then why are we not negotiating the other way; downwards and both ways because we always find ourselves in a position to satisfy donor requirements. We serve so many donors and they all have different requirements ...the following is not politically correct but it is a fact that resources are still located at the top and the cultures are different. There is still a culture of superiority plus the resources... ${ }^{16}$

However, this is not to say INTERFUND has not made any achievements, it has. And yet these achievements say nothing about agenda setting. According to Renald Morris of the Open Society Foundation in South Africa, donors assist in setting the agenda for NGOs but they do not go as far as telling them what kind of work that they should be doing. He noted:

Unfortunately, I do not have first hand information of having spoken to donors but based on a wide range of NGOs that we interact with on a daily basis, there seems to be a very strong movement by donors to set the agenda for NGOs. I think so, partly as you would know that if you talk collectively all donor funding that comes to the country amounts to less than 3 percent of the annual budget of the country. Even though it translates to hundreds of millions of Rands ${ }^{17}$, there is 
not much that goes around to actually sustain these NGOs to work. So NGOs are really desperate for survival. The other thing that I think has acted negatively or forced NGOs to accept this agenda by donors is that the National Development Agency has been slow in releasing funds to NGOs. Just speaking to beneficiaries and the way we interact, and I am not saying we do not have an agenda, we have an agenda in terms of programmes, we need to support the broader mission of the organization but we will not in any way force an organization and say this is what you have to do. What we ask for is that programs need to have an evaluation component. Now if some NGOs see that as an agenda by the Foundation, then that probably could be seen as pushing our own agenda. But we are saying funding is scarce and because our funding is limited to our experience, we need to be very sure that the work we are funding has a particular impact because part of our agenda is to disseminate learning in the sector and push NGOs to be innovative in the work that they are doing. ${ }^{18}$

Mokgapi Maleka, a senior Project Officer also at Open Society Foundation concurred with Morris. He said:

I know that the organization I work for has a clear agenda, to promote democracy, - that's the agenda. And in cases where NGOs are contracted, I would imagine they are forced to conform to that philosophy that the organization stands for. We treat NGOs as independent entities but make sure that they do not go out to do their own things, whatever we agree on they have to do it. ${ }^{19}$

And Piroshaw Camay, director of CORE, echoed the same sentiments. He argued:

Often donors come along and say we have a Civil Society Strengthening Programme or a governance program and yet those agendas have been set in Washington, London, Paris or wherever. So often-local NGOs bid for work and agree to do that work which is really the donor's agenda, it's definitely not the local agenda. The trick is how to implement changes so as to create a local agenda. That is really the skill. ${ }^{20}$

\section{Donors and funding guidelines: Bad tools or sources of creativity?}

The above remarks indicate that donors can directly influence the 
agenda priorities of the recipient organizations through their funding guidelines, mission statements and objectives. Guidelines serve to ensure responsibility and accountability for funds. ${ }^{21}$ However, the questions that need to be asked are whether this is a bad practice when these guidelines define and determine the agenda for recipient organisations? How do they do this? Gary Hawes of the Ford Foundation suggested an answer when he said:

I am sure that our partners are intelligent human beings and they know what some of our priorities are and they would shape proposals to meet those priorities. I do not want to sound over cynical, but it is a fact of life that NGOs and CBOs have to scramble to find funding to implement the projects and programs. So it is in their best interest to get to know what the priorities of the donor are and see how their goals might overlap with the goals of the Foundation. ${ }^{22}$

Hawes's comments seem to agree with what Tvedt(1998) argues: that in order to access money, NGOs tend to describe the local needs in the aid language prevailing at any one point in time, as a means of maintaining organisational activities as well as for the sake of the oppressed. In the same line, Alicia Pieterse of INTERFUND commented:

I was a director of an NGO before and you learn to play the game. What I used to do was to match the needs of the community. I never used to just draft a standard proposal. I used to adjust the needs of the community to suit whichever donor's criteria. I would want to know that we have leaders who are passionate enough about local agendas but are also equipped enough to go back to the office and write a proposal in such a way that it can generate funds, because you can not do without funds. So what I am saying is that we have to report to these people in a very sophisticated way. You must understand that even here we have to be schizophrenic. We live in a third world environment but report to the first world people. So the reporting has to be in the first world standard, highly sophisticated. But when you go to the field, you surely do not want to be sophisticated but reality is, when you come back to the office and you have to present problems of that community, you have to do it in a sophisticated first world standard ${ }^{23}$.

However the problem with funding guidelines it seems, according to Ben Fani, co-coordinator of the National Network of Community Based Organisations, that proposals are expected to be formulated in 
terms of what donors are known to be prepared to fund rather than in terms of what communities themselves have determined to be their priorities (Development Update 2001, vol.3. no. 4, 37). However Christopher Landsberg, a lecturer in International Relations at the University of the Witwatersrand, had a different argument. He argued that some NGOs do not have an agenda for what they want to do.

They go to the donors to raise funds for their agenda. They do this by asking what the donor is funding that particular year. They then go back to their offices to write proposals in line with the funding guidelines of the donor. ${ }^{24}$

In the context of isomorphic change formulated by Walter Powell and Paul DiMaggio, one can argue that the more uncertain and ambiguous the goals of these organisations, the greater the extent to which they will model themselves upon organisations that they depend on. ${ }^{25}$ Whether this is a bad practice or not is the question. What is clear though is the fact that at times donors do not have to directly put pressure on the NGO or set its agenda. Landsberg has a more simple explanation. He says that "The NGO is just gullible and conforms to the donor's agenda without any conditionality." 26

This view, however, misses the opportunistic element in the search of NGOs for funding to survive, even though it is true that such organisations jump from one particular plan of action to another in order to access funding, as Abie Dithlake, director of SANGOCO, maintained. He argued:

If one moves from the point of understanding that philanthropy is generally not an innocent thing, it is based on particular interests and particular needs of the philanthropists, there is no doubt of the impact of the donor community on NGOs especially as they are very dependent on that philanthropy. This impact happens in a number of ways. First, they determine what needs to happen because donors say these are our priorities and this is what we fund. We see that many people then go to develop proposals in line with what the donors perceive to be the priorities. Second, we see NGOs jumping from one particular issue to the next, for example from gender to HIV-AIDS because that is where money happens to be at that particular time. That in itself does not reflect what the particular nation needs and what the priorities are at that point in time. This reflects largely donor driven programmes. ${ }^{27}$ 
Dithlake's views could be matched with those of Steven Friedman of the Centre for Policy Studies, who questioned cynically the motives of some NGOs. He asked,

Why do people want to be part of civil society? What's so special about being part of civil society? Why is somebody who is part of civil society better than somebody who is not? Everybody wants to be part of civil society because donors give money to civil society. ${ }^{28}$

These views show that jumping from one issue to the other could really be problematic especially if organisations end up taking projects that they have no expertise in or have very broad objectives that look fancy but unachievable. According to a 1999 CPS study, many CBOs had difficulty providing a clearly defined set of objectives and priorities. Many of their mission statements conveyed a strong commitment to values and principles such as social justice, equity, non-racialism, gender equality, human rights, democracy and freedom. These (laudable and unrealistic) aims, according to this study, were formulated to appeal and attract funders (Core/ Idasa 2001: 49). This is a situation where organisations knowingly, unknowingly and-or willingly are influenced by what donors are funding in a way that is detrimental. This is a problem.

\section{The problem}

The problem with guidelines as the evidence suggests is that they might facilitate lip service by NGOs to the issues. NGOs end up doing something completely new, different from their initial vision. For Xolela Mangcu, director of the Steve Biko Foundation:

There are a lot of things that NGOs are doing that they would not do were it not for funders. If funding were not a major concern, these NGOs would be honest with themselves. There are things that have to do with issues of identity, issues of consciousness and issues of values that NGOs are not attending to. A lot of NGOs develop this isomorphic syndrome; they begin to transform themselves to chase the money. ${ }^{29}$

And according Morris, NGOs end up chewing more than they can swallow. ${ }^{30}$ The problem here is that if the only reason for being an organisation is to chase money and survive then there is something very wrong which needs attending to. There is obviously no 
commitment and passion to the vision of the organisation and donors should be very wary about this. However, according to some donors, this appears to be something that they identify with ease. There are solutions to this problem. According to Jan Nijzink, director of the Regional Office of Hivos for Southern Africa:

It is not difficult to see through applications. We never ask NGOs to write proposals based on our priorities. It is a big mistake if NGOs think they will get money because they have read our document. That would be very opportunistic of NGOs. We look at the experience of the NGO and if it is a new NGO, we look for the experience of the donors who are funding the NGO. It is very easy to find out if an NGO is just paying lip service for example on gender. ${ }^{31}$

\section{The solution}

It seems therefore to us that funding guidelines can influence NGO priorities but this can be overcome through mechanisms to test the commitment of the NGO. The Ford Foundation, for example, spends quality time with its grantees. Ford Foundation staffs make site visits, evaluate what they have accomplished and at the end of the process reach a consensus on goals to be pursued. ${ }^{32}$ The Mott Foundation also has a regular process of feedback and reflection and thinking through what is needed. According to Christa Kuljian:

We have an on-going relationship with our grantees. We do not want to say we negotiated this grant, here is the money, we will see you in three years, good luck. We want to have an on-going communication and be able to learn from the experiences of our grantees. ${ }^{33}$

Eugene Saldanha of the NPP also commented on the relationship between his organisation and its donors (Mott, Ford and Atlantic Philanthropies). He said:

It is excellent. The advantage with Mott is that we have found them not only to be a grantmaker; we have found them to be a partner. In the Income Tax lobby, Mott has attended our meetings, made suggestions at the substantive levels...Mott has contributed in a way that goes just beyond just giving us a cheque. Those are the kinds of relationships that we look forward to our funders, where they understand the work we do, support it and are simply not an organization that gives a cheque. ${ }^{34}$ 
It seems therefore that NGOs develop their own mission, and on the basis of that mission, they develop a set of work plans. They then take these plans to international donors who then fund them on the merits of their proposals and their capacity. They do this in response to particular needs in the NGO sector and in South Africa. The NPP, for example, responds to problems related to the financial sustainability of the sector. Mott, Ford and other donors support the NPP's work on the basis of how it has delivered. This has been the primary drive for funding NPP. ${ }^{35}$ The same applies to organisations like CPS, INTERFUND, CSVR and many others. It seems very true that both donors and NGOs respond to problems and issues on the ground. There is a coming together of minds. Alice Brown (Director, Ford Foundation) captured this when she said:

An example would be HIV-AIDS. Everyone realizes that it is a problem facing South Africa. Donors, NGOs, CBOs and individuals realize this. There will be some groups, be they CBO or NGO who would respond to the problem by developing different programmes on HIV-AIDS and in turn because I am a donor who wants to be responsive to real issues and problems on the ground, I am going to be receptive to requests that are targeted at dealing with the pandemic. So it's not a matter of me as a donor setting the agenda, I do not think the donor should set the agenda. And for that matter I do not think the NGO can set an agenda in a vacuum. The issues set the agenda and the problems facing the communities in which we work (donors, NGOs and CBOs) and that is what we all need to be responding to. ${ }^{36}$

What we can say at this moment is that it seems that the development agenda in South Africa's non-profit sector is set by the context. Donors and grantees have been responding to needs of the communities that they serve. However in doing this, NGOs should be evolutionary. For instance, during the apartheid period, it was important and it made sense for public interest law centres to fight apartheid laws and focus their attention on promoting and protecting civil and political rights. In 2003, this is no longer pertinent; most people have civil and political rights. What people lack are social and economic rights. It thus makes sense for public interest law centres which previously fought pass laws, lobbied for freedom of expression, association etc, to shift their work and deal with issues of housing, access to clean water and towards realising that social 
and economic rights are guaranteed under the new constitution. This is an example where groups are not corrupting their mandate but are responding and adapting to contextual needs. We observe that there is overwhelming evidence which suggests that it is not always true that paying the piper means calling the tune. From our study, this happens in very rare and extreme cases. One of these cases, according to Abie Dithlake is when

Ruthless donors, who in the event that that they failed to achieve what they wanted through their activities begin to have a direct and political role in coercing and determining who should be the people and leaders of the particular organization before they could fund it. $^{37}$

Another case is where the grantee does not have a diversified funding base. Alice Brown (a donor) alluded to this when she said

We do not want a grantee to be solely dependent on us; it is not a healthy relationship. It is not healthy for any recipient to be solely dependent on one source of funding... Some organizations have done well in diversifying their funding bases and therefore will not be so completely or totally be subject to the whims or will of one or two donors. That is the best position to be in. ${ }^{38}$

While we have maintained that donors are not setting the agenda for the their grantees, we have also observed that it is very easy for smaller organisations to succumb to the demands of a donor if their funding base is not diversified. This can be said to be a creation of donors. Donors tend to have a weakness for funding bigger and more professional organisations that have a good track record at the expense of smaller grassroots based organisations. As a result of this, smaller grassroots organisations have no leverage to resist the demands of the donor. Resisting the demands may translate into losing the grant. This is a serious weakness and it is very common among donor foundations.

\section{A common weakness}

Most of the donor organisations that we looked at share a common weakness. They tended to fund larger, professional, and urban organisations with a proven track record. One donor said: 
I think that one area of weakness with quite a few international donor agencies is that we tend to fund larger, more established NGOs that happen to be in big cities in Gauteng, Natal, Western Cape and Braamfontein. ${ }^{39}$

This has also been echoed at the grassroots level. Ben Fani, commenting on the state of community based organisations, argued in 1998 that changes in donor practice favoured larger, sophisticated and urban non-governmental bodies at the expense of smaller, grass-roots organisations, which are no longer able to meet the more rigorous criteria and reporting requirements of Northern donors. ${ }^{40}$ The book Funding Virtue: Civil Society and Democracy Promotion also discusses this issue. Marina Ottaway and Thomas Carothers observe that donors end up concentrating on a very narrow set of organisations. These are the professionalised urban NGOs that focus mainly on issues directly related to democratisation. Marina Ottaway argues that the organisations that this aid targets are creations of donor funding rather than of social demands for representation. This has resulted in many of these organisations tending to resemble each other in the leadership, programmes and ideological outlook. They tend to be much closer to the donors' preferences than to the needs of the supposed constituencies. Bluntly put by Christopher Landsberg:

At times donors tend to have a buddy-buddy relationship with particular NGOs. They know the individual who can write the best proposal that suits their demands but not the needs and the critical nature of the work and simply give support on that basis. ${ }^{41}$

This view obviously misses the contractual nature of relationships and the fact that outcomes are measurable. But supposing such relationships exist, the question would be; why is this? Who should carry the blame? Xolela Mangcu has one answer. He argues:

You cannot blame donors when NGO leaders have no guts to stand up for their own ideas. Do donors seem to influence local organizations? Of course they do, but the extent to which they influence depends on the quality of leadership of the organization. ${ }^{42}$

Mangcu's views seem to discard the notion that NGOs are vulnerable to a donor-driven agenda. While we agree that this is 
true of organisations with quality leadership, we are nevertheless not very convinced about the extent to which this can be advanced by smaller CBOs and other NGOs that do work that does not fall into the priorities of many donors. Research organisations, for example, seem to us to be very vulnerable to a donor driven agenda. Steven Friedman, director of CPS, a research organisation, for instance, explained that while CPS stood and fell by its independence, it faced difficulties in accessing funding to carry through its own research agenda. He said:

We try to develop our own research agenda. However we must be honest, most of the time a lot of what we are doing is not our research agenda, it is the donor's research agenda. But that does not mean we are total slaves. We try within that to do as much our own research agenda as we can. Sometimes we succeed in persuading the donor that our research agenda is worth funding... There is no way that I can look you in the eye and say that we have entirely our own agenda and we do not do what the donors want us to do. No research organization would look you in the eye and tell you that. It won't be telling you the truth. It is not possible to survive even for one day if you take that attitude. If you are asking me, are we simply slaves of the donors? Then I would get angry because we do get lucky and manage to persuade our donors that what we want to do is what they want to fund. Secondly we do not just take it at face value. We discuss and negotiate. We would not do the work, which we think is totally out of our experience and research interest. ${ }^{43}$

While it is clear that there are challenges that the sector is facing, it is also true that there are mechanisms to meet these challenges.

\section{Meeting challenges}

It is very clear from Friedman's comments that research organisations, for example, can develop their agenda but it is more difficult for them to follow through their entire agenda even if good leadership is present. Donors will have something that they want researched. This is not true of CPS only. It is also true of CSVR, CORE and other research organisations as well. Mott's support, for example, for CSVR's Transition and Reconciliation Unit was to ensure the continuation of the process of transition and reconciliation in South 
Africa. Ford's support to the same organisations also has its own objectives. To CSVR, the Ford Foundation's objective was to evaluate the Truth and Reconciliation Program and the Gender Project. And to also examine the patterns, causes and prevention of violence. To meet these challenges, however, these organisations have put in place systematic plans to attain sustainability over a period of time. For instance, they have developed marketing strategies for their publications to generate income, and perhaps more successfully, have developed consultancy units that charge for services.

\section{Conclusion}

In this paper, we looked at the extent to which donors impact on the development agenda of civil society organisations in South Africa. While this study is not a universal sample, its findings, nevertheless, may apply to other donors and NGOs as well that are not covered here. Based on the organisations that we looked at, there is evidence that suggests that the relationship between donors and NGOs is complex. It is true that most NGOs are dependent on donors. However the extent to which this dependence helps donors exert their leverage on NGOs in the prioritisation of programs is problematically debatable. What is clear though, is that dependence on external donor funding can shape the NGO's agenda in ways determined by broad donor priorities. However, NGOs are able to negotiate their agenda within the broad parameters of the guidelines. And this is not to say there are no challenges that NGOs and donors encounter in their relationship. The position that International Fundraising Consortium (INTERFUND) occupies, as discussed earlier, presents an example of challenges that other intermediary organisations could face in South Africa. INTERFUND finds itself having to satisfy many donor demands and yet still be accountable to the community-based organisations that it supports. A balance has to be struck between donors and grantees. Problems on the ground must inform policy as well as set donor and NGO priorities. As Alice Brown put it, the agenda must be set not by the donor or the NGO, but by the context. We conclude therefore by stating that while there are many challenges that NGOs face in South Africa, they have not sacrificed themselves to donors. They have achieved 
this by diversifying their funding bases. However what this paper did not explore, which might be worth doing, is the impact that internal funding may have on the same NGOs if suddenly they were to get support from domestic sources like the National Development Agency. We recommend further research on this because we believe that there is more internal funding to the sector as shown by The Size and Scope of the Non Profit Sector in South Africa. And this makes us rethink the arguments that have been developed about the sector's vulnerability to international donors and their agendas. We also want to make a note that our study did not look at the impact funding has on grassroots organisations in its analysis. We recommend a further study on these. We believe relations with their grantors may be different from the ones that we looked at, that tended to be bigger and located in urban areas.

\section{References}

Advisory Committee. 1997. Structural Relationships between government and civil society organizations, A report by the Advisory Committee, prepared for the Deputy President, the Hon. Thabo Mbeki.

Blair, H. 1997. 'Donors, Democratization and Civil Society; Relating Theory to Practice',' in NGOs, States and Donors: Too Close for Comfort?, (eds.). D. Hulme and M.Edwards, Macmillian Press, London, 23-42. Bratton. M and Landsberg. C. 2000. 'South Africa', in Good Intentions, Pledges of Aid for Post Conflict Recovery, Shepard Forman and Stewart Patrick, (eds.), London, Lynne Rienner, 259-314.

Budlender, D. 1999. The Fourth Women's Budget, Idasa, Cape Town.

Burkeman. S. 2001. 'An unsatisfactory company..?', Development Update, Vol.3. No.4, INTERFUND, Braamfontein.

Carothers, T. 1997. 'Democracy assistance: the question of strategy', Democratization, 4 (3), 109-132.

Carothers, T and Ottaway, M. 2000. Funding Virtue. Civil Society Aid and

Democracy Promotion, Carnegie Endowment for International Peace, Washington, D.C.

Core/Idasa. 2001. Two Commas and a Full Stop, Civicus Index on Civil

Society, South Africa Country Report, SANGOCO, Johannesburg.

Escobar, A. 1995. Encountering Democracy: The making and the unmaking of the third world, Princeton University Press, Princeton. 
Fisher, J. 1998. Non-Governments: NGOs and the Political Development of the Third World, Kumarian Press, Connecticut

Friedman, S. and Reitzes, M. 1996. 'Democratic Selections? Civil Society and Development in South Africa's New Democracy', in Transformation in South Africa? Policy Debates in the 1990s, E.Maganya and R. Houghton, (eds.), IFAA and EDA Trust, Johannesburg, 230-250.

INTERFUND/SANGOCO. 2001. Development Update, Annual Review: The Voluntary Sector and Development in South Africa, (1999/2000), Vol 3, No 3.

INTERFUND/SANGOCO. 2001. Development Update, The Learning Curve: A Review of government and voluntary sector development delivery from 1994, Vol3, No 4.

Habib, A. and Taylor, R. 1999. 'South Africa: Anti-Apartheid NGOs in Transition', Voluntas, International Journal of Voluntary and Non Profit Organisations, Vol. 10, No. 1, 73-83.

Hancock, G. 1989. Lords of Poverty: The Power, Prestige and Corruption of the International Aid Business, Atlantic Monthly Press, New York.

Hearn, J. 1998. 'Foreign Political Aid, Democratisation and Civil Society in South Africa since 1994', mimeo.

Hearn, J. Foreign Aid, Democratisation and Civil Society in Africa: A study of South Africa, Ghana and Uganda, Discussion paper 368.

Hudock, A.C. 1999. NGOs and Civil Society. Democracy by Proxy? Polity Press, Cambridge.

Hulme, D. and Edwards, M. 1997. 'NGOs, States and Donors', in NGOs, States and Donors: Too Close for Comfort?, D. Hulme and M.Edwards, (eds.), Macmillian Press, London, 3-22.

Hutchful, E. 1995. 'The Civil Society debate in Africa', International Journal, Vol. 51 Winter.

Lancaster, C. 1999. Aid to Africa: So much to do, So little done, The University of Chicago Press, Chicago.

Landsberg, C. 2000. 'Voicing The Voiceless: Foreign Political Aid to Civil Society in SouthAfrica', in FundingVirtue, Civil SocietyAidandDemocracy Promotion, Marina Ottaway and Thomas Carothers, (eds.), op cit. Lipschutz, R D. 1992. 'Reconstructing World Politics: The emergency of Global Civil Society', Millennium, Vol. 21, No 3, 389-420.

Riddell, R and Bebbington, A. 1995.Developing Country NGOs and Donor Governments: Report to the Overseas Development Administration, London, Overseas Development Institute. 
Riddell, R and Bebbington, A 1995. 'The direct funding of Southern NGOs by Donors: New Agendas and Old Problems', Journal of International Development, Vol 7, No. 6, 879-893.

Riddell, R and Bebbington, A 1997. 'Heavy hands, Hidden Hands, Holding Hands? Donors, Intermediary NGOs and Civil Society Organisations', in NGOs, States and Donors, Too Close for Comfort?, 107-127.

Robinson, M 1995. 'Strengthening civil society in Africa; the role of foreign political aid', IDS Bulletin, 26(2); 70-80.

Robinson, M. 1996. 'The role of aid donors in strengthening civil society', in A. Clayton (ed.), NGOs, Civil Society and the State: Building Democracy in Transitional Societies, Oxford, INTRAC.

Robinson, M. 1998. 'Civil Society in Africa: a conceptual overview', mimeo.

Swilling, M 2002. The Size and Scope of the Non-Profit Sector in South Africa, Centre for Civil Society Studies, University of Natal, Durban.

Stacey, S. and Aksartova, S. 2001. 'The Foundations of Democracy: U.S. Foundation Support for Civil Society in South Africa, 1988-1896', Voluntas, Vol.12, No. 4.

Tvedt, T. 1998. Angels of mercy or development diplomats, NGOs and Foreign Aid, Africa World Press, Trenton.

Van Rooy, A and Robinson, M. 1998. 'Out of the ivory tower; civil society and the aid system', in A.van Rooy (ed.), Civil Society and the Aid Industry, London, Earthscan.

\section{Annual Reports}

The Charles Stewart Mott Foundation Annual Reports 1995, \& 2000.

The C.S. Mott 2001 Facts and Grants.

The Ford Foundation Annual Reports, 1999 and 2000.

INTERFUND Annual Report, 2000-2001.

Hivos Annual Report 2000.

\section{Notes}

1. We use the word donor to refer to foundations that are supporting civil society organizations in South Africa. This support can be financial or technical. The word donor is not used in this paper to refer to an individual or individuals. 
2. For the emergence and role of NGOs in general, see Brown and Korten (1991), Tvedt (1998), Jorgensen (1996), Farrington \& Bebbington (1993), Hadenius (1996), Naidoo (1997), Hulme \&Edwards (1996). Korten (1991), Blair (1997), Van Rooy (1998) among others.

3. A lot of literature on NGOs in South Africa testifies to this fact and most of my respondents concurred with this observation.

4. Steven Burkeman argues that donor-recipient relations are inherently unhealthy because they reflect unequal power relations (Burkeman 2001:152).

5. Private foundations that we referred to in this study are mainly American. These are The Open Society for South Africa, The Ford Foundation and The Charles Stewart Mott Foundation. In addition, we use European foundations such as The Humanistic Institute for International Development (HIVOS) and The Atlantic Philanthropies. Among the development organisations most of whom are grantees of the above foundations, we use: The Steve Biko Foundation, Centre for the Study of Violence and Reconciliation, Centre for Policy Studies, The International Fundraising Consortium, The Group for Environmental Monitoring, The South Africa NGO Coalition, The Cooperative for Research and Education, The Non Profit Partnership, The Southern Grant Makers Association and Mvula Trust.

6. See for example the list of demands that women made to be incorporated into the Freedom Charter in 'What Women Want', www.anc.org.za/ ancdocs/history/women/demand.html.

7. Andre Gunder Frank (1967) discusses this in Capitalism and Underdevelopment in Latin America, and also in Neo-Colonialism in West Africa (1973), probably influenced by the works of Walter Rodney (1972), How Europe Underdeveloped Africa.

8. See for example the discussion by Hollis Chenery and Allan Strout (1966), Foreign Assistance and Economic Development.

9. This seems to agree well with the new book by Joseph Stiglitz, Globalisation and Its Discontents, which looks critically at the misguided policies of the International Monetary Fund and the World Bank towards developing countries.

10. See also a study by Howard White (1992), The Macroeconomic Impact of Development Aid: A Critical Survey, Paul Mosley (1995) Aid Effectiveness, and Peter Boone (1994) The Impact of Foreign Aid on Savings and Growth.

11. This definition was agreed upon after conflicting ideas by South African researchers, academics and practitioners on the definition offered by The CIVICUS Index Project, which had defined civil society as: the 
sphere of institutions, organizations, networks and individuals (and their values) located between the confines of the family, the state and the market, which is bound by a set of shared civic rules, and in which people associate voluntarily to advance common interests (Core/Idasa 2001: 3).

12. Hulme and Edwards also used this to refer to pressures for co-optation of recipient organisations by donors.

13. Interview with Christa. L. Kuljian (Braamfontein), 5 March 2002.

14. David Hulme and Michael Edwards (1996) discuss the effects of dependency in detail in NGOs, States and Donors: Too Close for Comfort... They say that although the evidence is inconclusive, there are signs that greater dependence on funding may compromise $\mathrm{NGO} /$ GRO performance in key areas and distort accountability and weaken legitimacy.

15. This discussion about the impact of international funding should also be understood in the context of South Africa's transition to democracy and the route donors took. First, we must remember that after 1994, most donors rerouted support to fund the democratic government directly. Thus NGOs were hard hit by diminishing budgets. Second, there was an exodus of people from the NGO sector to government departments. The sector therefore was affected by both human resource as well as the financial constraints. Hence according to Chetty (2000) this diminution in the pool of donor funding and rechannelling to government has forced many CSOs to bow to the pressures of funder demands. Thus the agenda and plans of institutions becomes funder driven. For a detailed history of international funding to South Africa, Christopher Landsberg and Michael Bratton are worth reading in Good Intentions..., pp259-314.

16. Interview with Alicia Pieterse (Braamfontein), 8 March 2002. Beni Fani also alludes to this issue. He says 'donors own and control these resources...Sometimes, a donor's agreement to make funds available has strings attached, some obvious, some hidden'. Development Update, Vol. 2. No. 1. 1998.

17. The Rand is the South African currency.

18. Interview with Renald Morris (Braamfontein), 4 March 2002.

19. Interview with Mogkapi Maleka (Braamfontein), 22 February 2002.

20. Interview with Phiroshaw Camay (Johannesburg), 7 March 2002.

21. Interview with Zakes Hlathswayo (Braamfontein), President of SANGOCO, 8 April 2002.

22. Interview with Gary Hawes (Braamfontein), 13 March 2002.

23. Interview with Alicia Pieterse op cit. 
24. Interview with Christopher Landsberg (Witwatersrand University), 6 March 2002.

25. Terje Tvedt argues that donor money and donor policies shape organisational landscapes in other countries and this creates the dilemma between organisations' external dependency and their roots in society (p.5).

26. Interview with Chris Landsberg, op cit.

27. Interview with Abie Dithlake (Braamfontein), 23 April 2002.

28. Interview with Steven Friedman (Doornfontein), 12 February 2002.

29. Interview with Dr. Xolela Mangcu (Braamfontein), 4 March 2002.

30. Interview with R.Morris, op cit.

31. Interview with Jan Nijzink (Harare, Zimbabwe) 27 May 2002.

32. Interview with Gary Hawes and Alice Brown (Braamfontein), 13 March 2002.

33. Interview with Kuljian, op cit.

34. Interview with Saldanha, op cit.

35. Interview with Saldanha, op cit.

36. Interview with Alice Brown (Braamfontein), 13 March 2002.

37. Interview with Dithlake, op cit.

38. Interview with Brown, op cit.

39. Interview with Kuljian, op cit.

40. See the article 'Sacrificed to the donor gods: community-based organizations' struggle for survival', Development Update Vol. 2. No. 1. 1998 pp37-40.

41. Interview with Landsberg, op cit.

42. Interview with Mangcu, op cit.

43. Interview with Friedman, op cit. 